\title{
A complexity hierarchy-based solution to the clausal subject puzzle in Turkish
}

\author{
Duygu Göksu \& Balkız Öztürk Başaran*
}

\begin{abstract}
This paper presents a novel analysis of subordinate clause structure in Turkish, focusing on subordinations formed by the following three suffixes: the infinitival $-\mathrm{mA}(\mathrm{K})$ with tenseless and (ir)realis usages, and -DIK/ -(y)ACAK with a (non)future temporal specification. We present a classification aligning each form on the Implicational Complementation Hierarchy ( $\mathrm{ICH})$ proposed in Wurmbrand and Lohninger (2020), which provides a solution for the subject puzzle observed with these clauses: only infinitival $-\mathrm{mA}(\mathrm{K})$ clauses with their (ir)realis use are compatible with being the subject of a transitive verb. We propose that (ir)realis infinitival clauses belong to the situation class in the $\mathrm{ICH}$, and that this middle class is of the ideal semantic complexity and syntactic size for a clausal subject in Turkish.
\end{abstract}

Keywords. complementation; embedded clause; external argument; nominalization; subject; Turkish

1. Introduction. It is possible to form embedded clauses in Turkish by adding a 'nominalizer' suffix to the embedded verb. Then, the embedded subject is genitive case marked and there is possessive agreement on the embedded predicate. This is illustrated in (1a-c) with the three nominalizers we focus on in this paper: -DIK with a non-future and -(y)ACAK with a future temporal specification, and the infinitival $-\mathrm{mA}(\mathrm{K})$.
a. Ayla [Ali-nin git-tiğ-in-i]
Ayla.NOM Ali-GEN leave-NMLZ-POSS.3.SG-ACC
'Ayla thought that Ali left.'
b. Ayla [Ali-nin gid-eceğ-in-i]
'Ayla thought that Ali will leave.'
Ayla.NOM Ali-GEN leave-NMLZ-POSS.3.SG-ACC thought
c. Ayla [Ali-nin git-me-sin-i] istedi.
Ayla.NOM Ali-GEN leave-INF-POSS.3.SG-ACC wanted
'Ayla wanted that Ali to leave.'
sandi.
thought
sand1.

The infinitival $-\mathrm{mA}(\mathrm{K})$ appears in control structures as well. Then, the possessive agreement morpheme on the embedded predicate is absent, as in (2).

(2) Ayla $_{i} \quad\left[\mathrm{PRO}_{i}\right.$ git-mek $]$ istedi.

Ayla.NOM leave-INF wanted

'Ayla wanted to leave.'

Among the three, -DIK and -(y)AcAK behave as allomorphs that come with different temporal specifications. They are selected by the same class of verbs, which are mostly different from those that select a clause formed with the infinitival $-\mathrm{mA}(\mathrm{K})$. However, a few verbs like şaşır 'be surprised' can take any of the three as its complement, as shown in (3).

\footnotetext{
* We would would like to thank Benjamin Mericli for his valuable input on earlier versions of this paper, Elena Guerzoni for her input on the original analysis in the Master's Thesis of the first author that this paper is based on, and the reviewers and audience of the LSA Annual Meeting in 2020. Authors: Duygu Göksu, University of Massachusetts, Amherst (dgoksu@umass.edu) \& Balkız Öztürk Başaran, Boğaziçi University (balkiz.ozturk@boun.edu).
} 
Ayla [Ali-nin git-tiğ/ece $\breve{g} / \mathbf{m e}$-sin-e] şaşırd1.

Ayla.NOM Ali-GEN leave-NMLZ/INF-POSS.3.SG-DAT was.surprised

'Ayla was surprised that Ali left/that Ali will leave/at Ali's leaving.'

These nominalizers and/or the clauses they form have so far been analyzed as 'action' vs. 'factive' nominalizers (Lees, 1965; Erguvanl1-Taylan, 1998), 'indicative' vs. 'subjunctive' 'degreed nominalizations' (Kornfilt, 2001; Kornfilt, 2003), and 'properties of events' vs.

'propositions' (Demirok, 2019). Based on the adverbial modification they allow, they have also been analyzed as nominalizations of TPs (Göksu, 2017) following Cinque's (1999) cartographic system for adverbial modification.

It has also been shown that -DIK/-(y)AcAK clauses are never selected by object experiencer verbs like şaşırt- 'surprise', and memnun et- 'please' and thus, never receive the causer theta role. Hence, they are not generated as external arguments and do not appear as subjects of transitive verbs (Göksu, 2018). This contrast is shown in (4a-b); a head noun like haberi 'news' needs to be present for the $-\mathrm{DIK} /-(\mathrm{y}) \mathrm{AcAK}$ clause, but not for the infinitival $-\mathrm{mA}(\mathrm{K})$ clause.
a. [Ali-nin git-tiğ/eceğ-i
*(haberi)]
Ayla-yı şaşırttı.
Ali-GEN leave-NMLZ-POSS.3.SG news.CM
Ayla-ACC surprised
'The news that Ali left/will leave surprised Ayla.'
b. [Ali-nin git-me-si] Ayla-yı şaşırttı.
Ali-GEN leave-INF-POSS.3.SG Ayla-ACC surprised
'Ali's leaving surprised Ayla.'

Without such a head noun, -DIK/-(y)AcAK clauses are typically theme arguments and can only be promoted to the subject when the main predicate is a passivized verb (5a), a one-place nonverbal predicate $(5 b)$, or when the other DP argument is lexically case-marked (5c).
a. [Ali-nin git-tiğ/eceğ-i]
düşünüldü.
Ali-GEN leave-NMLZ-POSS.3.SG was.thought
'It was thought that Ali left/will leave.'
b. [Ali-nin git-tiğ/eceğ-i] doğru.
Ali-GEN leave-NMLZ-POSS.3.SG is.true
'It is true that Ali left/will leave.'

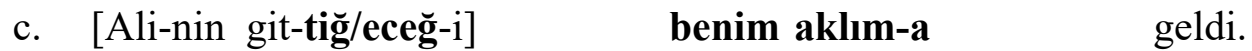
Ali-GEN leave-NMLZ-POSS.3.SG I.GEN mind.POSS.1.SG-DAT came
Lit. 'It came to my mind that Ali left/will leave.'

Focusing on the contrasts between (4) and (5), we propose that these embedded clauses differ in their semantic complexity. Specifically, the situation class infinitival nominalizations are preferred by the grammar as clausal subjects (of transitive verbs). We reach this conclusion by comparing the 'independence properties' of all three nominalizations and placing them into different categories on the Implicational Complementation Hierarchy proposed in Wurmbrand and Lohninger (2020), given in Table 1 below.

\begin{tabular}{ccc}
\hline Proposition & Situation & Event \\
-DIK/-(y)AcAK & $\mathrm{mAK}_{1}$ & $\mathrm{mAK}_{2}$ \\
\hline
\end{tabular}

Table 1. Classification of nominalized clauses in Turkish 
In section 2, we briefly go over the details of the ICH proposal in Wurmbrand and Lohninger (2020). Then in section 3, we show that -DIK/-(y)AcAK clauses seem to be the most independent nominalized clause type, belonging to the proposition class. In section 4 , we present data that suggest there are two types of infinitival clauses: situation and event, depending on the matrix verb selecting them. In section 5, we show that the clauses that appear as the subject of a transitive verb have the same independence properties as situation complements. In section 6 we conclude that the situation class clauses have the ideal semantics and syntax for being generated as an external argument and appearing as the subject of a transitive verb in Turkish.

2. Implicational complementation hierarchy. Building on Givón (1980)'s binding hierarchy, and previous observations that complement clauses can be grouped into three classes: propositions, situations, and events (Wurmbrand, 2001; 2014a, 2015), Wurmbrand and Lohninger (2020) put forward the Implicational Complementation Hierarchy given in Table 2 below.

\begin{tabular}{lll}
\hline Most independent & Peast independent \\
Least transparent & Proposition $>>$ Situation $>>$ Event & $\begin{array}{l}\text { Most transparent } \\
\text { Least integrated }\end{array}$ \\
Most integrated \\
\hline
\end{tabular}

Table 2. Implicational complementation hierarchy (ICH)

In this hierarchy, independence as a property refers to, for example, whether the embedded subject or tense information can be independent from that of the matrix clause; transparency relates to how transparent the embedded clause is for certain operations; and integration concerns the degree of incorporation with the matrix predicate. Some examples of matrix verbs that select a proposition, situation, or event complement in English given in Wurmbrand and Lohninger (2020), are listed in (6a-c), below.

a. Proposition: admit, affirm, announce, assume, believe, claim, consider, discover, figure, find, forget (factive), imagine, know (factive), observe, say, suppose, tell (speech), wager

b. Situation: agree, ask, choose, decide, demand, desire, know (modal), need, plan, promise, refuse, tell (imperative), want, wish

c. Event: avoid (implicative), begin, can, continue, fail, finish, forget (implicative), manage, may, must, start, stop, succeed, try

The complementation hierarchy is implicational in that a given class of complements in a language is never more independent, less transparent, and less integrated than the class of complements on its left on the hierarchy. That is, for any of the independence properties given in (7) below, if a class of complements have that property, one on its left on the hierarchy will also have them.

(7) (Wurmbrand and Lohninger 2020: 39)

Independence properties: nominative case, structural object case, overt subject, independent subject interpretation, agreement, tense marking, finiteness, independent temporal interpretation, negation, syntactic domain effects, lack of transparency, indexical shift, clausal operators, lack of morphosyntactic integration of the embedded verb into the matrix predicate (e.g, incorporation, verb cluster, complex predicate formation) 
Lastly, the three classes of complements come with different minimal syntactic structure requirements. Following Ramchand and Svenonius (2014), it is proposed that there is a containment relationship between them: the combination of time/world parameters with an existentially closed event results in a situation, and propositions are products of combining speakeroriented/discourse-linking parameters with an existentially closed situation. The complexity of a complement and its minimal syntactic structure requirements are given in Table 3 below.

\begin{tabular}{cccc}
\hline & Proposition & Situation & Event \\
Minimally required & Operator domain, & TMA domain, & Theta domain \\
domains & TMA domain, & Theta domain & \\
Complexity & Theta domain & Intermediate & Least complex \\
\hline
\end{tabular}

Table 3. Complement composition (Wurmbrand and Lohninger 2020, Table 13)

3. -DIK/(y)AcAK clauses are propositions. As we stated earlier, the embedded subjects of these complements can be overt, receive genitive case, and agree with the embedded verb via possessive agreement. The embedded subjects also receive an independent interpretation from that of the matrix clause as they cannot be controlled. These are shown in (8a-c), with an overt embedded subject different from the matrix subject, or an optionally co-referential silent $3^{\text {rd }}$ person pronoun, and a non-coreferential $1^{\text {st }}$ person pronoun that can be left silent.
a. Ali $_{\mathbf{i}}$
[Aylin -in $^{-10}$
gel-diğ/eceğ-in-i]
biliyor.
Ali.NOM Aylin-GEN come-NMLZ-POSS.3.SG-ACC knows

'Ali knows that Aylin came/will come.'
b. Alii
$\left[\boldsymbol{\emptyset}_{\mathbf{i} / \mathbf{k}}\right.$
gel-diğ/eceğ-in-i]
biliyor.
Ali.NOM
come-NMLZ-POSS.3.SG-ACC knows

'Ali knows that (s/he) came/will come.'
c. Ali
$\left[\left(\right.\right.$ ben $_{\mathbf{j}}$-im) $) \mathbf{\sigma}_{\mathbf{j}}$
gel-diğ/eceğ-im-i]
biliyor.
Ali.NOM
I-GEN
come-NMLZ/INF-POSS.1.SG-ACC
knows

'Ali knows that (I) came/will come.'

In addition to independent subject interpretation, -DIK/(y)AcAK complements come with independent temporal specifications of their own. While -DIK has present or past (i.e. non-future) time specification, -(y)AcAK comes with future. This is illustrated in (9a-b) with separate adverbs in each clause.
a. Ali
[Aylin-in
(dün/şimdi/yarın)
gel-diğ/eceğ-in-i]

Ali.NOM Aylin-GEN yesterday/now/tomorrow come-NMLZ-POSS.3.SG-ACC

\section{az önce duydu.}

a.bit ago heard

'Ali heard a little bit ago that Aylin came yesterday/ has just come/ will come tomorrow.'

b. Ali [Aylin-in (dün/şimdi/yarın) gel-diğ/eceğ-in-i]

Ali.NOM Aylin-GEN yesterday/now/tomorrow come-NMLZ-POSS.3.SG-ACC

bu akşam duyacak.

tonight will.hear

'Ali will hear tonight that Aylin came yesterday/ has just come/ will come tomorrow.' 
As another independence property, structural accusative case is available for an embedded object, when the matrix verb is in both active and passive voice, as shown in (10).
a. $\mathrm{Ali}_{\mathrm{i}}$
[Aylin ${ }_{\mathrm{j}}$-in
on ${ }_{i}-\mathbf{u} \quad$ sev-diğ/eceğ-in-i]
biliyor.
Ali.NOM
Aylin-GEN
he-ACC like-NMLZ-POSS.3.SG-ACC
knows

'Ali knows that Aylin liked/likes/will like him.'
b. [Aylin
on $_{\mathrm{i}-\mathbf{u}}$ sev-diğ/eceğ-i]
biliniyor.
Aylin-GEN he-ACC like-NMLZ-POSS.3.SG.NOM is.known
'That Aylin liked/likes/will like him is known.'

Likewise, the embedded verb can be negated, as in (11).
$\mathrm{Ali}_{\mathrm{i}}$
[Aylin ${ }_{\mathrm{j}}$-in
on $_{i}-\mathbf{u} \quad$ sev-me-diğ/eceğ-in-i]
biliyor.
Ali.NOM Aylin-GEN he-ACC like-NEG-NMLZ-POSS.3.SG-ACC knows
'Ali knows that Aylin did/does/will not like him.'

Another property that shows they are propositions is the lack of transparency for A-movement of an embedded object. In a Long Passive structure, in which both verbs are in passive voice, Amovement of the embedded object is not available with them, as shown in (12).

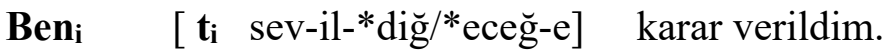
I.NOM like-PASS-NMLZ-DAT was.decided
Lit. 'I was decided that (I) was/will be liked.'

They can also license indirect wh-questions, like in (13).
Ali
[Aylin-in
neyi
sev-diğ/eceğ-in-i]
sordu.
Ali.NOM Aylin-GEN what.ACC like-NMLZ-POSS.3.SG-ACC asked
'Ali asked what Aylin likes/liked/will like.'

However, they are not full CPs either, because they lack indexical shift and their subjects cannot be in nominative case, as shown in (14a-b).
Ali $\mathbf{i}_{\mathbf{i}}$
$[$ ben $*$ i-im
öl-düğg/eceğ-im-i]
sand1.
Ali.NOM
I-GEN
die-NMLZ-POSS.1.SG-ACC
thought
'Ali thought that $\mathrm{I} /{ }^{*}$ he died/was dying.'

Overall, based on the independence properties and the lack of transparency effects observed with -DIK/(y)AcAK nominalizations, we conclude that they belong to the proposition class.

4. $-\mathbf{m A}(\mathbf{K})$ (infinitival) complements are situations or events. We propose that depending on the verb that selects them, infinitival nominalized clauses in Turkish belong to two different complementation classes: situations or events. Expectedly, they share similar properties different that distinguish them from proposition class complements, and they also differ from each other, with the situation class showing more independence than the event class.

Following Wurmbrand and Lohninger's (2020) classification, situation class infinitives are those that are typically selected by non-obligatory control verbs that allow partial control, like karar ver- 'decide' and iste- 'want'. Event class infinitives are selected by obligatory control verbs that do not allow partial control, like başla- 'start'and çalış- 'try'. In a subject control structure, they look very similar, as in (15a-b), with both embedded verbs lacking agreement marking on them, but only the former allows partial control. 


\begin{tabular}{|c|c|c|c|}
\hline $\begin{array}{l}\text { a. } \text { Ali }_{\mathbf{i}} \\
\text { Ali.NOM }\end{array}$ & $\begin{array}{l}{\left[\mathbf{P R O}_{\mathbf{i}+} \text { kafede }\right.} \\
\text { at.the.café }\end{array}$ & $\begin{array}{l}\text { toplan-ma-ya] } \\
\text { gather-INF-DAT }\end{array}$ & $\begin{array}{l}\text { karar verdi. } \\
\text { decided }\end{array}$ \\
\hline 'Ali decidec & gather at the cat & & \\
\hline $\begin{array}{l}\text { b.\# Ali } \mathbf{i}_{\mathbf{i}} \\
\text { Ali.NOM }\end{array}$ & $\begin{aligned} & {\left[\mathbf{P R O}_{* i+}\right.} \text { kafede } \\
& \text { at.the.café }\end{aligned}$ & $\begin{array}{l}\text { toplan-ma-ya] } \\
\text { gather-INF-DAT }\end{array}$ & $\begin{array}{l}\text { çalıştı. } \\
\text { tried }\end{array}$ \\
\hline
\end{tabular}

Lit. 'Ali tried to gather at the café.'

Another distinguishing factor is that in a situation class infinitival complement, it is possible to have an optionally silent genitive embedded subject with independent interpretation. This is not available with an event class complement. This contrast is shown in (16a-b).

$$
\begin{aligned}
& \text { a. } \text { Ali }_{i} \quad\left[\text { Aylin }_{\mathbf{j}}-\mathbf{i n} / \mathbf{p r o}_{\mathbf{j}} \text { gel-me-sin-e }\right] \quad \text { karar verdi. } \\
& \text { Ali.NOM Aylin-GEN come-INF-POSS.3.SG-DAT decided }
\end{aligned}
$$

Lit. 'Ali decided on Aylin's/(her) coming.'

$$
\text { b. }{ }^{*} \mathrm{Ali}_{\mathrm{i}} \quad \text { [Aylin } \text { j-in }_{\mathrm{j}} \text { gel-me-sin-e] çalıştı. }
$$

Ali.NOM Aylin-GEN come-INF-POSS.3.SG-DAT tried

Lit. 'Ali tried for Aylin to come.'

Thirdly, in control structures with situation class complements, the embedded event needs to follow the matrix event, which makes them irrealis, whereas event type infinitives are interpreted as being realized simultaneously with the matrix event. This is illustrated in (17a-b) with two different time adverbs, yarın 'tomorrow' and dün 'yesterday', modifying embedded and matrix events, respectively. ${ }^{1}$
a. $\mathrm{Ali}_{\mathrm{i}}$
[PRO $\mathrm{i}$ yarın
gel-me-ye]
dün karar verdi.
Ali.NOM tomorrow come-INF-DAT
yesterday decided

'Yesterday, Ali decided to come tomorrow.'
b. Ali $_{i}$

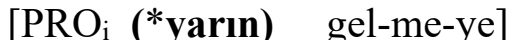
dün
çalışt1.
Ali.NOM tomorrow come-INF-DAT yesterday tried
'Yesterday, Ali tried to come (*tomorrow).'

As for the availability of structural case, under an active voiced matrix verb, both types of infinitives allow an embedded accusative object. This is given in (18a-b).
a. $A l i i_{i}$
$\left[\mathrm{PRO}_{\mathrm{i}}\right.$ Aylin-i sev-me-ye] karar verdi.
Ali.NOM Aylin-ACC
like-INF-DA
decided

'Ali decided to like Aylin.'

$\begin{array}{llll}\text { b. } \text { Ali }_{\mathrm{i}} & \text { [PRO }_{\mathrm{i}} \text { Aylin-i } & \text { sev-me-ye }] & \text { çalıştı. } \\ \text { Ali.NOM } & \text { Aylin-ACC } & \text { like-INF-DAT } & \text { tried }\end{array}$

'Ali tried to like Ayla.'

\footnotetext{
${ }^{1}$ Also, realis usage is possible with agreement marking on the embedded situation infinitive, like in (i).

i. Ali [Aylin-in git-me-sin-e] üzüldü.

Ali.NOM Aylin-GEN leave-INF-POSS.3.SG-DAT was.upset

'Ali was upset at Aylin's leaving.'
} 
On the other hand, when the matrix voice is passive, the structural accusative case is still available only in situation class infinitives, as in (19a-b), suggesting events are restructuring infinitives. $^{2}$
a. Aylin-i
sev-me-ye karar verildi.
Aylin-ACC like-INF-DAT was.decided

Lit. 'It was decided to like Aylin.'
b. *Aylin-i sev-me-ye çalışıldı. Aylin-ACC like-INF-DAT was.tried

Lit. 'It was tried to like Aylin.'

In both types, the embedded verb can be negated. This is shown in (20a-b).
a. $\mathrm{Ali}_{\mathrm{i}}$
$\left[\mathrm{PRO}_{\mathrm{i}}\right.$ Aylin-i
sev-me(-me)-ye]
karar verdi.
Ali.NOM
Aylin-ACC
decided

'Ali decided to (not) like Aylin.'
b. Ali ${ }^{2} \quad\left[\mathrm{PRO}_{\mathrm{i}}\right.$ Aylin-i
Ali.NOM Aylin-A
sev-me(-me)-ye] çalıştı.
Ali.NOM Aylin-ACC like-INF-NEG-DAT tried
'Ali tried to (not) like Ayla.'

In contrast to propositions, both the situation and the event type complements allow Amovement of the embedded object in a Long Passive structure, as given in (21a-b).
a. $\mathbf{A l i}_{\mathbf{i}}$
[t $\mathbf{t}_{\mathbf{i}}$ kov-ul-ma-ya]
karar verildi.
Ali.
fire-PASS-INF-DAT
was.decided

Lit. 'Ali was decided to be fired.'
b. Ali $_{i}$
[t $\mathbf{t}_{\mathrm{i}}$ kov-ul-ma-ya]
çalışıldı.
Ali.
fire-PASS-INF-DAT
was.tried

Lit. 'Ali was tried to be fired.'

Also, neither can form an indirect question with an embedded wh-word, like in (22a-b).

$$
\begin{aligned}
& \text { a. } \mathrm{Ali}_{\mathrm{i}} \quad\left[\mathrm{PRO}_{\mathrm{i}} \text { ne yap-ma-ya }\right] \text { karar verdi?/*. } \\
& \text { Ali.NOM what do-INF-DAT decided }
\end{aligned}
$$

'What did Ali decide to do?/ *Ali decided what to do.'
b. Ali $_{i}$
$\left[\mathrm{PRO}_{\mathrm{i}}\right.$ ne
yap-ma-ya]
çalıştı?/*.
Ali.NOM
what do-INF-DAT
tried

'What did Ali try to do?/ *Ali tried what to do.'

However, similar to propositions, neither the situation nor the event complements allow indexical shift, as in (23a-b). ${ }^{3}$
a. $\mathbf{A l i}_{\mathbf{i}}$
[benim $*_{\mathrm{i}}$
git-me-m-e]
karar verdi.
Ali.NOM I.GEN leave-INF-POSS-DAT decided

'What did Ali decide to do?/ *Ali decided what to do.'

\footnotetext{
${ }^{2}$ See Göksu (2020) for details on restructuring infinitives in Turkish.

${ }^{3}$ Notice that in (23b), we used a structure with infinitive and the postposition için 'for' that would allow in some dialects for the overt embedded subject that regular event complements would not, so that we can test the possibility of an indexical shift. However, it is still not available.
} 


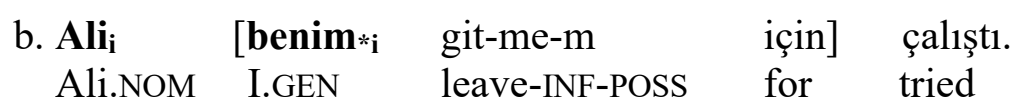

'What did Ali decide to do?/ *Ali decided what to do.'

To conclude, based on the lack of independence properties like licensing indexical shift and indirect questions and the presence of transparency for A-movement, we conclude that neither type of infinitival complement has the operator domain in its syntax. While the infinitives selected by non-obligatory control verbs have more independence in their subject and temporal interpretations, the infinitives selected by obligatory control verbs do not. Hence, we claim that the first type belongs to the situation class while the second belongs to the event class.

5. Proposal: Subject clauses are situations. The overall distribution of relevant properties of all three complements we presented so far is summarized in Table 4 below.

\begin{tabular}{cccc}
\hline $\begin{array}{c}\text { Properties\Complement } \\
\text { Negation on embedded } \\
\text { verb }\end{array}$ & $\begin{array}{c}\text { Proposition } \\
\text {-DIK/(y)AcAK }\end{array}$ & $\begin{array}{c}\text { Situation } \\
-\mathbf{m A}(\mathbf{K})_{1}\end{array}$ & $\begin{array}{c}\text { Event } \\
-\mathbf{m A}(\mathbf{K})_{2}\end{array}$ \\
$\begin{array}{c}\text { Structural case for the } \\
\text { object }\end{array}$ & $\checkmark$ & $\checkmark$ & $*$ \\
$\begin{array}{c}\text { Independent subject } \\
\text { interpretation }\end{array}$ & $\checkmark$ & $\checkmark$ & $*$ \\
$\begin{array}{c}\text { Independent temporal } \\
\text { interpretation } \\
\text { Lack of transparency } \\
\text { for A-movement } \\
\text { Indirect question for- } \\
\text { mation }\end{array}$ & $\checkmark$ & $\checkmark$ & $*$ \\
$\quad$ Indexical shift & $\checkmark$ & $*($ irrealis $)$ & $*$ \\
\hline
\end{tabular}

Table 4. Distribution of independence properties in clausal complements in Turkish

The alignment of the independence properties on the table clearly obeys $\mathrm{ICH}$; any property that an event complement has, so does the situation and the proposition complement. Likewise, any property that a situation has, so does the proposition complement. The opposite implication also works; the only property a proposition lacks is also not available for a situation or an event complement. Similarly, independence properties that situations lack are also lacking in events.

Based on this clear distribution, we propose that the minimal domain in -DIK/(y)AcAK clauses is the operator domain, although probably not the whole CP layer since indexical shift is not possible with them. Infinitival clauses that are situations lack the operator domain but have the TMA domain in their syntax; again, not the whole TP because they are just (ir)realis, not fully tensed. Lastly, event complements lack both the operator and the TMA domain, and only have the theta domain. This is summarized in Table 5 below. 


\begin{tabular}{cccc}
\hline & Proposition & Situation & Event \\
& -DIK/(y)AcAK & $-\mathbf{m A}(\mathbf{K})_{1}$ & $-\mathbf{m A}(\mathbf{K})_{2}$ \\
Operator domain, & TMA domain, & Theta domain \\
Minimally required & TMA domain, & Theta domain & \\
domains & Theta domain & Intermediate & Least complex \\
\hline
\end{tabular}

Table 5. Complement composition in Turkish nominalizations

Now how does this classification help us explain the subject puzzle we introduced earlier in the paper? The key data is repeated here in $(24 a-b)$.
a. [Ali-nin git-tiğ/ece $\breve{g}-i$
*(haberi)]
Ayla-yı
şaşır-t-tı.
Ali-GEN leave-NMLZ-POSS.3.SG news.CM
'The news that Ali left/will leave surprised Ayla.'
b. [Ali-nin git-me-si] Ayla-yı şaşırttı.
Ali-GEN leave-INF-POSS.3.SG Ayla-ACC surprised
'Ali's leaving surprised Ayla.'

While an infinitival complement can appear as the subject of a transitive verb like şaşırt- 'surprise', -DIK/(y)AcAK complements need a head noun to be able to appear in the same position.

The contrast is especially surprising because the same verb (without the causative voice marker) şaşır- 'be surprised', can take any of the three as its (oblique) argument, repeated here in (25).

$$
\begin{aligned}
& \text { Ayla [Ali-nin git-tiğ/eceğ/me-sin-e] şaşırdı. } \\
& \text { Ayla.NOM Ali-GEN leave-NMLZ/INF-POSS.3.SG-DAT was.surprised } \\
& \text { 'Ayla was surprised that Ali left/that Ali will leave/at Ali's leaving.' }
\end{aligned}
$$

It was proposed in Göksu (2018) that the theta role assigned to the embedded clauses in (24a-b) is the causer, while the theta role in (25) is the target (Pesetsky, 1995), and that the contrast is related to restricted compatibility with the causer role possibly due to the different semantic types of the embedded clauses. Building on this, we propose that the causer role is only compatible with the syntax and semantics of situation class complements in Turkish.

In the rest of this section, we present data that shows clausal subjects of transitive verbs have the same independence properties as situation complements. Firstly, like situation complements, a partial control relation between the PRO subject of a subject infinitive and the experiencer argument of the matrix verb is available, as in (26).

$$
\begin{aligned}
& \text { [PRO }{ }_{i+} \text { kafede toplan-mak] Ali } \mathbf{i}_{-} \text {-yi mutlu etti. } \\
& \text { at.the.café gather-INF.NOM Ali.ACC happy made. }
\end{aligned}
$$

Secondly, a genitive case marked embedded subject with independent interpretation is possible, coming with agreement morphology on the embedded verb, and it can be left silent, like in (27).
$\left[\right.$ Aylin $_{\text {-in }} /$ pro $_{\mathbf{i}}$
eve
dön-me-si]
Ali $\mathbf{i}_{\mathrm{j}}$-yi
mutlu etti.
Aylin-GEN
home.DAT return.INF-POSS.3.SG.NOM
Ali.ACC
happy made
'Aylin's/(her) coming back home made Ali happy.' 
Thirdly, the clauses come with realis temporal interpretation, as shown in (28). The embedded event must precede the matrix event, just like situation complements but in contrast to both propositions and events.

$$
\left[\mathrm{PRO}_{\mathrm{i}}\right.
$$

(dün/bugün) iş-

birak-mak]

Ali $i_{i}$-yi (bugün/*dün)

mutlu etti. yesterday job-ACC quit-INF.NOM Ali.ACC today/yesterday happy made.

'To quit the job yesterday/today made Ali happy today/*yesterday.'

Also like situation complements, subject infinitives have structural case available for an embedded object even when the matrix voice is passive, as in (29).

$$
\begin{array}{lccl}
\text { Toplantida } & \text { [Ali-yi } & \text { kov-mak }] \text { iste-n-di. } \\
\text { in.the.meeting } & \text { Ali-ACC } & \text { fire-INF.NOM } & \text { want-PASS-PST } \\
\text { 'To quit the job yesterday/today made Ali happy today/*yesterday.' }
\end{array}
$$

Based on the distribution of independence properties of clausal subjects of transitive verbs in Turkish, we infer that they belong to the ICH's situation class. In the next section we summarize and conclude.

6. Conclusion. This paper called into focus the restrictions on the types of Turkish nominalizations that can serve as the clausal subject of a transitive verb. Specifically, we looked for an explanation for why only certain infinitival complements can appear as the subject of a transitive verb. We placed each nominalized clause type on the Implicational Complementation Hierarchy of Wurmbrand and Lohninger (2020) using the transparency properties proposed there. The resulting picture was as follows: -DIK/-(y)ACAK clauses belong to the proposition class while infinitival complements formed with $-\mathrm{mA}(\mathrm{K})$ are either situations or events, depending on the verb that selects them. Finally, we showed the class of complements that can function as the subject of a transitive verb are situation class infinitives. This is summarized in Table 6 below.

\begin{tabular}{cccc}
\hline & Proposition & Situation & Event \\
$\begin{array}{c}\text { Subject of a transi- } \\
\text { tive verb }\end{array}$ & -DIK/(y)AcAK & $-\mathbf{m A}(\mathbf{K})_{1}$ & $-\mathbf{m A}(\mathbf{K})_{2}$ \\
$\begin{array}{c}\text { Object of a transi- } \\
\text { tive verb }\end{array}$ & $\checkmark$ & $\checkmark$ & $*$ \\
Complexity & Most complex & Intermediate & Least Complex \\
\hline
\end{tabular}

Table 6. Complement composition in Turkish nominalizations

Note that we are not claiming being the subject of a transitive verb as another independence property as it clearly does not obey ICH with propositions lacking it. One puzzle for future research is what about the class of situation complements, with their intermediate complexity in syntax and semantics, makes them the perfect embedded clause type for being external arguments in Turkish. One possibility is that the TMA domain is necessary, while the operator domain is prohibited, in clausal external arguments in Turkish. Hence, the problem with the other two types of complements is that event complements lack the TMA domain whereas propositions come with the operator domain. Further research with data from other languages could help paint a clearer picture. 


\section{References}

Cinque, Guglielmo. 1999. Adverbs and functional heads: A cross-linguistics perspective. New York: Oxford University Press.

Demirok, Ömer. 2019. A semantic characterization of Turkish nominalizations. In Richard Stockwell, Maura O'Leary, Zhongshi Xu \& Z.L. Zhou (eds.), Proceedings of the 36th West Coast Conference on Formal Linguistics,132-142. Somerville, MA: Cascadilla Press.

Erguvanl1-Taylan, Eser. 1998. What determines the choice of nominalizer in Turkish nominalized complement clauses? In Bernard Caron (ed.), Proceedings of the XVIth International Congress of Linguists. Oxford: Pergamon.

Göksu, Duygu. 2017. Typology of nominalizations formed with $\{-\mathrm{DIK}\},\{-\mathrm{mA}\},\{-(\mathrm{y}) \mathrm{Iss}\}$, and $\{-\operatorname{Im}\}$ in Turkish. In Y1lmaz Köylü \& Jaklin Kornfilt (eds.), IULC Working Papers in Linguistics 18(2). Bloomington, IN: Indiana University.

Göksu, Duygu. 2018. Subject infinitives in Turkish. Istanbul: Boğaziçi University MA thesis.

Göksu, Duygu. 2020. Restructuring infinitives in Turkish. [Manuscript]. Amherst, MA: University of Massachusetts.

Givón, Talmy. 1980. The binding hierarchy and the typology of complements. Studies in Language 4. 333-377.

Kornfilt, Jaklin. 2001. Functional projections and their subjects in Turkish clauses. In Eser Erguvanl1-Taylan (ed.), The verb inTurkish, 183-212. Philadelphia: John Benjamins.

Kornfilt, Jaklin. 2003. Subject case in Turkish nominalized clauses. In Uwe Junghanns \& Luka Szucsich (eds.), Syntactic structures and morphological information, 129-215. New York: Mouton de Gruyter. https://doi.org/10.1515/9783110904758.129.

Lees, Robert. 1965. Turkish nominalization and a problem of ellipsis. Foundations of Language 1. 112-121.

Pesetsky, David. 1995. Zero syntax. Cambridge, MA: MIT Press.

Ramchand, Gillian \& Peter Svenonius. 2014. Deriving the functional hierarchy. Language Sciences 46. 152-174. https://doi.org/10.1016/J.LANGSCI.2014.06.013.

Wurmbrand, Susi. 2001. Infinitives: Restructuring and clause structure. New York: Mouton de Gruyter.

Wurmbrand, Susi. 2014a. Restructuring across the world. In Ludmila Veselovská \& Markéta Janebová (eds.), Complex visibles out there. Proceedings of the Olomouc Linguistics Colloquium: Language use and linguistic structure, 275-294. Olomouc: Palacký University.

Wurmbrand, Susi. 2015a. Complex predicate formation via voice incorporation. In Léa Nash \& Pollet Samvelian (eds.), Approaches to complex predicates, 248-290. Leiden: Brill.

Wurmbrand, Susi. 2015b. Restructuring cross-linguistically. In Thuy Bui \& Deniz Özyıldız (eds.), Proceedings of the North Eastern Linguistics Society Annual Meeting 45, 227-240. Amherst, MA: University of Massachusetts GLSA.

Wurmbrand, Susi \& Magdalena Lohninger. 2020. An implicational universal in complementation: Theoretical insights and empirical progress. In Jutta M. Hartmann \& Angelika Wöllstein (eds.), Propositionale Argumente im Sprachvergleich: Theorie und Empirie. [Studien zur Deutschen Sprache]. Tübingen: Gunter Narr Verlag. https://ling.auf.net/lingbuzz/004550. 